\author{
WILHELM ReES \\ University of Innsbruck, Austria \\ (D) https://orcid.org/0000-0002-1439-3162
}

\title{
Synods and Synodality in the Austrian Church after the Second Vatican Council
}

\begin{abstract}
Synods have a long tradition in the ecclesiastical history, though their significance varied in different epochs of the Roman Catholic Church. Within the European area, synods gained in importance after the Second Vatican Council, although they appeared in a new or rather modified form. This also applies to the diocesan synods and the Austrian Synodal Process (1973/1974), which took place after and has been celebrated by the supporters of the Second Vatican Council.

Keywords: Synodality, canon law, the Second Vatican Council, the Republic of Austria, Codex Iuris Canonici
\end{abstract}

\section{Impulses of the Second Vatican Council regarding church law applicable at the time}

A glance at the texts of the Second Vatican Council reveals the intention to revive synodal structures ${ }^{1}$ (cf. Art. 36 Abs. 1 VatII

${ }^{1}$ On the history of diocesan synod, see H. E. FeInE: Kirchliche Rechtsgeschichte, Volume I. Die Katholische Kirche. Köln 51972, pp. 215, 375 f., 713, 722; E. CAPPELLINI, G. C. S. SARTORI: Il synodo diocesano. Storia, normativa, esperienza. Milano 1994; H. Monceau: Les synodes diocésains. Paris 1994; T. Rozkrut: La natura teologico-giuridica del sinodo diocesano (= Ponticium Athenaeum Sanctae Crucis Facultas Iuris Canonici). Roma 1996; K. Niкolakopoulos: „Neutestamentliche Wurzeln der Synodalität.” In: Autorität und Synodalität. Eine interdisziplinäre und interkonfessionelle Umschau nach ökumenischen Chancen und ekklesiologischen Desideraten. Eds. C. BötTIGHEIMER, J. HoFmanN. Frankfurt am Main 2008, pp. 237-251; H. PaArhammer: "Die Diözesansynode 
CD). ${ }^{2}$ In detail the Council desires "that the venerable institution of synods and councils flourish with fresh vigour. In such a way faith will be deepened and discipline preserved more fittingly and efficaciously in the various churches, as the needs of the times require" (Art. 23 Abs. 2 VatII CD). Yet, Council did not instruct in detail how the revival should be implemented, "after a period of actual insignificance, which has primarily been caused by Roman centralism becoming more absolute," it resembles "expressis verbis a necessary extension of ecclesiastical hierarchy to the faithful." 3 Furthermore, implied suggestions as well as the realignment of ecclesiology coming along with a new view of the Church has been important to synodal practice. More precisely, the Church is described as the "People of God" (Art. 9-17 VatII LG; Art. 32 VatII LG). ${ }^{4}$ The Second Vatican Council also emphasises common priesthood (Art 10. VatII LG), ${ }^{5}$ proper position of the laity (Art. 30-38 VatII LG) as well as their participation in the three-fold office of Jesus Christ as Priest, Prophet, and King (cf. Art 34 VatII LG; Art. 10 Abs. 1 VatII AA) and the specific role of religious members (Art. 43-47 VatII LG). Moreover, the Church is seen as Communio ${ }^{6}$ (communio fidelium, communio hierarchia, communio eccle-

in ihrer gegenwärtigen Rechtsgestalt. Anmerkungen zum geltenden Recht und zu partikulären Neuentwicklungen des kirchlichen Synodalwesens auf Diözesanebene." In: Neue Positionen des Kirchenrechts. Eds. K. Lüdicke, H. PaArhammer, D. A. Binder. Graz 1994, pp. 81-117, esp. pp. 85-91.

2 Cf. G. BAuSEnhart: "Theologischer Kommentar zum Dekret über das Hirtenamt der Bischöfe in der Kirche." In: Herders Theologischer Kommentar zum Zweiten Vatikanischen Konzil. Vol. 3. Freiburg-Basel-Wien 2005, pp. 225-313, esp. pp. 287.

${ }^{3}$ K. Hartelt: Die Diözesan- und Regionalsynoden im deutschen Sprachraum nach dem Zweiten Vatikanum. Rechtshistorische und rechtstheologische Aspekte der Verwirklichung des Synodalprinzips in der Struktur der Kirche der Gegenwart (= Erfurter Theologische Studien, Volume 40). Leipzig 1979, p. 69; see also N. Wiтsch: entry "Synodalität." In: LKStKR, Vol. 3 (2004), pp. 642-644. Secondary literature unavailable in English is translated to the best of our knowledge.

${ }^{4}$ Cf. N. Witsch: entry "Volk Gottes." in: LKStKR, Vol. 3 (2004), pp. 840-842; P. ERDö: "Die Kirche als rechtlich verfaßtes Volk Gottes." In: HdbKathKR ${ }^{2}$, pp. 12-20; F. LAPPEN: Vom Recht zu reden und vom Recht gehört zu werden. Synoden und Foren als Mittel der Teilhabe der Gläubigen an den Leitungsfunktionen der Kirche in Deutschland (= Münsterischer Kommentar zum Codex Iuris Canonici, Beiheft 46). Essen 2007, pp. 4-9; W. Aymans: “Die Kirche - Das Recht im Mysterium Kirche.” In: HdbKathKR 3 , pp. 32-41, esp. pp. 33-35.

${ }^{5}$ I. Riedel-Spangenberger: entry “Gemeinsames Priestertum. II. Kath.” In: LKStKR, Vol. 2 (2002), pp. 44-45; T. Meckel: entry "Allgemeines bzw. Gemeinsames Priestertum - Katholisch.” In: LKRR, Vol. 1, pp. 83-87.

${ }^{6}$ Cf. I. Riedel-Spangenberger: entry “Communio.” In: LKStKR, Vol. 1 (2000), pp. 355-357; H. HallermanN: entry "Communitas fidelium." In: LKStKR, Vol. 1 (2000), pp. 357-359; T. MecKel: entry "Communio - Katholisch.” In: LKRR, Vol. 1, pp. 518520; H. Hallermann: entry “Gemeinde - Katholisch.” In: LKRR, Vol. 2, pp. 162 f. 
siarum). That kind of "theological characterisation is," as Hubert Müller mentions "of particular importance, because it forms the basis for ecclesiastical discipline on the one hand and for participation and joint responsibility at all levels on the other hand." The new view of the Church formed by the Second Vatican Council requires participation of all the people, in other words: of all the faithful in processes of decision making. The laity as members of the Church can and must not be excluded. Karl Rahner even mentions that "it is dogmatically possible to give an actual right of decision making binding Bishops Conferences as well as each bishop to Synod as such." 8

According to the view of the Church of CIC 1917, "the bishops build the second pillar of ecclesiastical constitution willed by God just behind the Pope, who carries full and supreme power over the entire Church (c. 218 connected with cc. $108 \S 3,196) . "{ }^{9}$ However, Norbert Witsch also mentions that there is a "varied network of synodal processes and institutions within the old CIC" 10 That CIC/1917 with its regulations on diocesan synods (cf. cc. 356-362 CIC/1917) and plenary- as well as provincial-councils (cc. 281-292 CIC/1917) as applicable law at the time was the basis for the Post-Conciliar Diocesan Synod as well as for the Austrian Synodal Process. ${ }^{11}$ There could and can only be a plenary council if "the Apostolic See gives its authorisation" (c. 439 §1 CIC/1983). As Stephan Haering critically remarks, "it is clearly noticeable that the development

${ }^{7}$ H. MülLER: "Kirchliche communio und Struktur der Mitverantwortung in der Kirche. Vom Zweiten Vatikanischen Konzil zum Codex Iuris Canonici.” In: AfkKR, Vol. 159 (1990), pp. 117-131, in here p. 118.

${ }^{8}$ K. Rahner: „Zur Theologie einer 'Pastoralsynode'““ In: Theologisches Jahrbuch 1973. Ed. S. HüBNER. Leipzig 1983, pp. 507-518, in here p. 513.

${ }^{9}$ N. Wiтsch: Synodalität auf Ebene der Diözese. Die Bestimmungen des universalkirchlichen Rechts der Lateinischen Kirche (= KStKR 1). Paderborn-München-WienZürich 2004, p. 29; S. N. WiтsCH: entry “Diözesansynode - Katholisch.” In: LKKR, Volume 1, pp. 644-646.

${ }^{10}$ N. WITsch: Synodalität (FN 9)..., p. 31; see R. PUZA: "Le principe synodale et les deux types des synodes entre le Code de 1917 et le Code de 1983." In: Synod and Synodality. Theology, History, Canon Law and Ecumenism in new contact. International Colloquium Bruges 2003 (= Christianity and History Vol. 1). Eds. A. Melloni, S. Scatena. Münster 2005, pp. 647-662.

${ }^{11}$ Cf. in detail Lehrbuch des Kirchenrechts auf Grund des Codex Iuris Canonici. Begründet von Eduard Eichmann, fortgeführt von Klaus Mörsdorf, Volume I: Einleitung, Allgemeiner Teil und Personenrecht $(=$ Wissenschaftliche Handbibliothek. Eine Sammlung theologischer Lehrbücher). München - Paderborn - Wien ${ }^{11} 1964$, pp. 424-426 und pp. 385-389; K. Hartelt: Regionalsynoden (FN )..., pp. 65-67; on Plenary Councils see H. Hallermann: "Die Würzburger Synode - ein Maßstab für synodale Prozesse?" In: Recht - Bürge der Freiheit. Festschrift für Johannes Mühlsteiger SJ zum 80. Geburtstag. Ed. von Konrad Breitsching und W. Rees (= Kanonistische Studien und Texte, Volume 51). Berlin 2006, pp. 621-644, in here pp. 624-627. 
of national-ecclesiastical tendencies was supposed to be disabled by that regulation." 12

\section{The Austrian Church after the Second Vatican Council}

Paul M. Zulehner remarked in 1974 that "Austrian ecclesiasticism has been exhausted during the last decades,"13 and that this process, which is indicated by a decline of church attendance, the increasing numbers of those leaving the Church and the decrease of ordination numbers, continues. He also calls attention to the fact that traditional forms of ecclesiasticism turn out to be exhausted not only at the margins of the Church. They evaporate within Her pivotal segments, too. "The Austrian Church faces this evaporation with a certain feeling of perplexity." 14 Richard Barta, the managing editor and the director of Austrian Catholic news agency Kathpress, evaluated the religious situation in Austria to the effect that: "[...] the Church lives in those people who do not have any objections against it." 15

Following the end of the Second Vatican Council, the desire for convocation of an Austrian national synod arose. ${ }^{16}$ A person who kindled this desire was Otto Mauer, who had been spiritual assistant of the Austrian Catholic Action since $1946^{17}$ and who "helped rebuilding the ecclesiasti-

${ }^{12}$ S. HAERING: "Autorität und Synodalität im Gesetzbuch der lateinischen Kirche." In: Autorität und Synodalität. Eine interdisziplinäre und interkonfessionelle Umschau nach ökumenischen Chancen und ekklesiologischen Desideraten. Eds. C. BöTtIGHEIMER, J. HoFMANN. pp. 297-320, in here pp. 302.

13 P. M. Zulehner: "Religiös-kirchliche Daten in Österreich.” In: HerKorr 28 (1974), pp. 580-584, in here p. 580, referring to P. M. ZulenNer: Verfällt die Kirchlichkeit in Österreich?. Graz 1971; see P. M. ZuleHner: Säkularisierung von Gesellschaft, Person und Religion. Religion und Kirche in Österreich. Wien 1973; P. M. ZuleHner: "Die kirchlichen Institutionen.” In: Das politische System Österreichs. Eds. H. Fischer. Wien 1974, pp. 625-641; on similiar tendencies in Germany, see F. Groner: "Trends in der katholischen Kirche im Bundesgebiet Deutschland nach dem Konzil.” In: HerKorr 28 (1974), pp. $251-257$

${ }^{14}$ F. CsокLICH: "Die a-religiöse Religiosität des Österreichers. Verdunstende Kirchlichkeit unter barocken Kringeln.” In: HerKorr 28 (1974), pp. 405-412, in here p. 408, referring to P. M. ZuLEHNER.

${ }^{15}$ Quoted from F. Csoklich: „Die a-religiöse Religiosität” (FN 14).., pp. 405 f. here 37.

${ }^{16}$ Cf. “Österreich-Synode im Aufschwung." In: HerrKorr 28 (1974), pp. 37-40,

${ }^{17}$ I. SchöDl: Vom Aufbruch in die Krise. Die Kirche in Österreich ab 1945 (= Editio Ecclesia semper reformanda 6). Innsbruck-Wien 2011, pp. 39 f. 
cal structures after 1945."18 Finally, Pope Paul VI had requested its application to ecclesial life at the end of the Second Vatican Council. ${ }^{19}$ So, the Austrian Church was the second one, just after the Dutch Church, to have given "thought on a National Synod." 20 The Austrian Church kept an eye on various synodal processes taking place in European countries: the Pastoral Council of Dutch Church (1968-1970), the Common Synod of German Dioceses (Würzburger Synode, 1971-1975), ${ }^{21}$ the Synod in Switzerland (Synode 72, 1972-1975) as well as the Pastoral Synod of Ecclesiastical Verges in GDR (1973-1975). In this process, the Würzburger Synode as well as the other assemblies were "new constructs regarding the canon law, since participants from all ecclesiastical classes took part in the discussions on an equal footing." 22

For the first time, Cardinal König officially brought up the plan of a Vienna diocesan synod during the Diocesan Men's Day in Wiener Neustadt (15 May 1965) and he reiterated this suggestion the night before the fourth session of the Second Vatican Council (13 September 1965) on broadcasted on television. "From Rome he gave the order to offices of pastoral care and the Catholic Action to make proposals on an Austrian National Synod."23 However, a consensus could not be reached during the spring meeting of the Austrian Bishops Conference (29 March 1966) and indeed the Austrian bishops spoke out against a nationwide Austrian Synod. ${ }^{24}$ Instead, the Austrian Church opted for the convocation and assembling of diocesan synods.

18 I. SCHÖDL: Aufbruch (FN 16)..., p. 49; see ibid., pp. 48-51; O. MAUER: "Situation 1965. Die österreichische Kirche im Zeitalter des ökumenischen Konzils." In: Kirche in Österreich 1918-1965, Vol. 1. Eds. F. Klostermann, H. Kriegl, O. Mauer, E. Weinzierl. Wien-München 1966, pp. 387-403.

${ }^{19}$ Cf. J. Ennesti: Paul VI. Der vergessene Papst. Freiburg-Basel-Wien 2012, pp. 79-86, pp. 107-109 and pp. 120-126; see? PAUlS VI: "Apostolisches Schreiben anlässlich des fünften Jahrestages der Beendigung des Zweiten Vatikanischen Konzils vom 8. Dezember 1970.” In: AAS 63 (1971), pp. 97-106; see also: http://www.kathpedia .com/index.php/Quinque_iam_anni_(Wortlaut) (accessed 5.02.2020); http://w2.vatican .va/content/paul-vi/la/apost_exhortations/documents/hf_p-vi_exh_19701208_quinque -iam-anni.html (accessed 5.02.2020).

20 “Synodenvielfalt in Österreich." In: HerKorr 25 (1971), pp. 34-37, here p. 34.

${ }^{21}$ Cf. H. Hallermann: entry “Gemeinsame Synode.” In: LKStKR 2 (2002), pp. 41-44; R. Althaus: entry "Gemeinsame Synode - Katholisch.” In: LKRR, Vol. 2, pp. 189-191.

22 S. Haering: "Autorität (FN 12)"..., s. 311, on the advice of H. HallermanN: „Würzburger Synode (FN)”..., pp. 629-637.

${ }^{23}$ Cf. "Übersicht über den Stand der synodalen Arbeit." In: Synode Wien. Information Bericht Dokumente 1 (1967), p. 1.

${ }^{24}$ There was merely one nationwide commission on studies in Austria, which convened on 7 June 1966 for the first time. On the ASP, see W. ReEs: "Der Österreichische Synodale Vorgang (1973/74). Vorgeschichte und kirchenrechtlicher Status." In: J. SchmiEDEL Nationalsynoden nach dem Zweiten Vatikanischen Konzil. Rechtliche Grundlagen und 
As a consequence, seven (Salzburg, Wien, Linz, Eisenstadt, Gurk, Innsbruck, St. Pölten) of the now nine Austrian dioceses celebrated diocesan synods ${ }^{25}$ : Salzburg (1968), ${ }^{26}$ Wien (1968-1971) ${ }^{27}$; Gurk/Kärnten (19701972) ${ }^{28}$ Linz (1970-1972) ${ }^{29}$ Innsbruck (1971-1972) ${ }^{30}$ St. Pölten (19711972) $)^{31}$ and Eisenstadt. ${ }^{32}$ The decision to set up a diocesan synod in the

öffentliche Meinung (= Theologische Berichte XXXV). Freiburg, Schweiz 2013, pp. 116198, here pp. 131-180.

${ }_{25}$ Cf. T. Неснт: Wir haben etwas zu sagen. Synodale Vorgänge in der Kirche Österreichs nach dem Zweiten Vatikanischen Konzil (=Diplomarbeit Katholisch-Theologische Fakultät der Universität Wien). Wien 1996; K. Hartelt: Regionalsynoden, pp. 45-58; D. BURKARD: "Diözesansynoden und synodenähnliche Foren sowie Kirchenvolksbegehren der letzten Jahrzehnte in den deutschsprachigen Ländern.” In: RQ 101 (2006), pp. 113140; W. Schulz: "Diözesan- und Regionalsynoden in den deutschsprachigen Ländern. Erfahrungen und Perspektiven.” In: La Synodalité. La participation au gouvernement dans l'Église. Actes du VII congrès international de Droit canonique, Paris, Unesco, 21-28 septembre 1990, Paris 1992, pp. 629-649, here pp. 630-643.

${ }^{26}$ H. WIDRICH (ed.): Erneuerung der Erzdiözese Salzburg durch lebendige Christengemeinden. Bericht und Dokumentation über die Salzburger Diözesansynode 1968 (= Dokumentation unserer Zeit). Wien 1969; С. Ноцвӧск: "Die Salzburger Diözesansynode 1968." In: Ius et salus animarum. Festschrift für Bernhard Panzram (= Sammlung Rombach, NF. Volume 15). Eds. U. von Mosiek, H. ZApp. Freiburg 1972, pp. 379-391; see Salzburger Diözesansynode 1968. Offizieller Text der Synodendekrete, Salzburg o. J. (1971); see R. Cerny-Werner: “Diözesansynode als sichtbares Zeichen. Die Ausrufung der Diözesansynode 1968 in Salzburg als nachkonziliarer und regionaler Locus Theologicus." In: Synodale Prozesse in der katholischen Kirche. Innsbruck 2016, pp. 19-34.

27 Cf. Erzbischöfliches Ordinariat Wien (ed.): Leben und Wirken der Kirche von Wien. Handbuch der Synode 1969-1971. Wien o. J. (1972); GenERALSEKRETARIAT DER WIENer DiöZESANSYNode In DEN JAhren 1967 BIS 1969 (ed.): Dokumentation der Wiener Diözesansynode 1967-69. Wien.

${ }^{28}$ Cf. Bischöfliches Ordinariat Der DiöZese Gurk: Kirche für die Welt. Kärntner Diözesansynode 1971-1972. Klagenfurt o. J. (1975).

29 Sekretariat Der LinZer Diözesansynode (ed.): Kirche um der Menschen willen. Linzer Diözesansynode 1970-1972. 2 Vols. Linz o. J. (1973).

30 Bischöfliches Ordinariat InNsbruck (ed.): Miteinander für alle. Das Pastoralprogramm der Diözese Innsbruck nach der Synode 1971-1972. Innsbruck o. J. (1974); W. ReEs: "Geistlicher Aufbruch — gestern und heute. Die Diözesansynode Innsbruck 1971/72 im Rahmen synodaler Prozesse. Anmerkungen aus kirchenrechtlicher Perspektive." In: Notae. Historische Notizen zur Diözese Innsbruck. Ed. Diözese InNsbrucK. Innsbruck 2014, pp. 112-146; W. ReEs: "Aufbruch durch die Diözesansynode 1971/72 in der neu errichteten Diözesen Innsbruck." In: Kirchlicher Wiederaufbau in Österreich (= Wissenschaft und Religion, Volume 26). Eds. H. Paarhammer, A. Rinnerthaler. Frankfurt am Main u.a. 2016, pp. 723-758; W. ReEs: “Die Diözesansynode Innsbruck 1971/72.” In: Synodale Prozesse (FN 26). Eds. W. ReEs, L. Müller, pp. 237-269.

31 Bischöfliches Ordinariat St. Pölten (ed.): Im Dienst an den Menschen. St. Pöltner Diözesansynode 1972. St. Pölten o. J. (1972).

32 Cf. Idem: Zweite Synode der Diözese Eisenstadt. Eisenstadt 1990; S. LÁszló: "Die Synoden der Diözese Eisenstadt. Ein Beitrag zur Rechts- und Kirchengeschichte." In: Pax et Iustitia (FN 46). Eds. Kaluza / Klecatsky / Köck / PaArhammer, pp. 591-599, esp. 
Diocese of Innsbruck (6 August 1964) ${ }^{33}$ was made while the Second Vatican Council was still ongoing and the alignment ended with eight votes against and fourteen for the motion. Bishop Rusch confirmed the decision, which was not acknowledged by all of the members due to its close voting result. Nevertheless, "Tyrol had made a mark" 34 with their Diocesan Synod in 1971/1972. Styria and Vorarlberg did not decide to call a diocesan synod. Even though the Diocese of Graz-Seckau prepared a Synod after the first Diocesan Synod in 1960, ${ }^{35}$ the change of the Bishop in 1968/1969 averted its convocation. The Diocese of Feldkirch has only been founded as an autonomous diocese in $1968,{ }^{36}$ which meant it was too early for their own synod. Finally, diocesan synods had the "advantage to involve wider circles of faithful than it may have been possible in the case of a national synod." ${ }^{37}$ In addition, diocesan synods provided an opportunity to learn in the view of a prospective national synod. Problems occurred on the part of large bodies and related to the question whether a theological background of the participants is necessary and by a wrongly rated time exposure. ${ }^{38}$

The genuine innovation of diocesan synods after the Second Vatican Council related to the legal participation of the laity. Since CIC/1917 did not foresee their participation, a special permission issued by the Apostolic See was required. It permitted the participation of the laity under

pp. 595-598; see DiöZeSE EisEnstadt (ed.): Diözese Eisenstadt auf dem Weg. Ihrem ersten Diözesanbischof DDr. Stefan László zum 80. Geburtstag. Redaktion Ägidius J. Zsifkovics. Innsbruck 1993.

33 Cf. "Päpstliche Bulle zur Errichtung der Diözese Innsbruck vom 6. August 1964." In: Verordnungsblatt für die Diözese Innsbruck, 40. Jg., 4. Jänner 1965, Nr. 1, TOP 1, p. 1 f.; J. Gelmi: "Die Errichtung der Diözesen Bozen-Brixen, Innsbruck-Feldkirch und Feldkirch. Eines der spannendsten Kapitel der neueren Tiroler Kirchengeschichte." In: Bischof Paulus Rusch. Wächter und Lotse in stürmischer Zeit. Gedenkschrift. Eds. H. Alexander, B. Kriegbaum. Innsbruck 2004, pp. 100-121; see also Seelsorgeamt DER Diözese InNsbruck (ed.): Ich bin bei Euch. Mt 28,20. 25 Jahre Diözese Innsbruck. Innsbruck o. J. (1989).

${ }^{34}$ K. Egger: "Kirche in Tirol - Geschichte und Gegenwart." In: Ich bin bei Euch (FN 37). Ed. Seelsorgeamt Der Diözese InnSbruck pp. 12-23, here p. 22.

35 Bischöfliches Seckauer Ordinariat in Graz (ed.): Der Laie in der Kirche. Seckauer Diözesansynode 1960. Bericht und Statut. Graz o. J. (1961); IDEM: Der Laie in der Kirche. Seckauer Diözesansynode 1960. Beiträge und Referate. Graz o. J. (1961).

${ }^{36}$ Cf. Hirtenbrief von Bischof Elmar Fischer zum Advent 2008. Schwerpunkt seines Hirtenbriefs ist das 40-Jahr-Jubiläum der Diözese: http://www.kath-kirche-vorarlberg .at/artikel/2008/40-jahre-dioezese-feldkirch-2013-zwischen-vergangenheit-und-zukunft (accessed 5.02.2020).

37 “Das Ende der Österreich-Synode.” In: HerKorr 28 (1974), pp. 368-372, here p. 368. The author remarks that the Swiss model would clearly have been exceptional.

38 Cf. Synodenvielfalt (FN 20), p. 34. 
certain circumstances ${ }^{39}$ whereby the relation between them and representatives of the clergy increasingly became the focus of attention. After the Apostolic See "initially allowed participation for the laity as fully entitled attendants, it restricted their participation to the extent that the number of lay persons must not exceed the number of priests. This reaction is seen as an almost fearful to certain calls for co-determination." 40 However, the restriction did not come from Rome, but from individual diocesan bishops. ${ }^{41}$

\section{The Austrian Synodal Process in 1973/1974}

As diocesan synods covered different areas and since the preparations along with the processes themselves revealed individual sectors exceeding the responsibilities of particular dioceses, the desire arose "to search for supra-diocesan coordination as far as possible." 42 As the person reporting it noted: "The different results of diocesan synods and the advantages of solving some problems - e.g. those regarding mass media nationwide, convinced the bishops of the necessity to hold a common 'umbrella-synod' as a synopsis and conclusion." ${ }^{43}$ The conference should not be held as a national council, but as a separate conference, which initially was named Gesamtösterreichischer Synodaler Vorgang and eventually called Österreichischer Synodaler Vorgang (ÖSV) - Austrian Synodal Process (ASP). It is impossible to file the ASP to CIC/1917, which was applicable at that time. ${ }^{44}$ Generally, naming as well as the intended process proved challenging and the thought of synods continued to have an effect for a long time. Thus, ASP was called "Österreichsynode" consistently during the preparations as well as during the process. According to

${ }^{39}$ These concessions were made in "anticipation of the reforms of CIC." Cf. H. Schmitz: "Die Beratungsorgane des Diözesanbischofs.” In: GrNKirchR, pp. 277-287, here p. 278 , FN 6.

${ }^{40}$ H. Schmitz: „Beratungsorgane” (FN 39)..., p. 278, FN 6.

${ }^{41}$ Cf. in detail ReEs: „Der Österreichische Synodale Vorgang (FN 24)”..., pp. 128 130.

42 „Österreich-Synode (FN 18)”..., p. 38.

43 „Das Ende (FN 35)”..., p. 368.

44 W. Rees: „Synoden und Konzile. Geschichtliche Entwicklung und Rechtbestimmungen in den kirchlichen Gesetzbüchern von 1917 und 1983." In: Unverbindliche Beratung oder kollegiale Steuerung? Kirchenrechtliche Überlegungen zu synodalen Vorgängen (= Europas Synoden nach dem Zweiten Vatikanischen Konzil). Eds. W. ReEs, J. SchmiedL. Freiburg-Basel-Wien 2014, pp. 10-67. 
Church law, ASP was no plenary council as scheduled by CIC/1917, and thereby "was protected against the Roman access." 45 Subordination to the Apostolic See was not requested and a "ecclesiastical vital process" should be "stressed and inspired." 46

Implementing the ASP was decided on 1 July 1970 by the Austrian Bishops Conference. Its inaugural meeting was on 7 March 1973 in Vienna, where also the first plenary session from 15 to 28 October 1974 took places. Likewise, the second plenary session, which has at once been the conclusion of ASP, took place from 1 to 5 May 1974 in Vienna. ASP was staged simultaneously with other common synods as the Würzburger Synode in Germany (1971-1975), ${ }^{47}$ the Niederländische Pastoralkonzil (19661970) ${ }^{48}$ the Synod 72 in Switzerland $(1972)^{49}$ and the Pastoral Synod of Jurisdiktionsbezirk in the GDR (1973-1975). ${ }^{50}$ From among 50 proposed topics, which had been formulated by the Austrian dioceses ex ante, four were selected: "Carriers of Ecclesiastical Service," "Church in Present Society," "Formation and Education" and "Church and Mass Media." The ASP was problematic in no way and it was evaluated differently. This applies not only to its reception and its particular impact on religious life in Austria,

45 „Das Ende (FN 45)”..., p. 368.

46 A. WAGNer: „Kirche in Österreich nach der Synode.” In: Lebendige Seelsorge 27 (1976), pp. 105-110, here p. 105.

${ }^{47}$ See S. Voges: "Die Gemeinsame Synode der Bistümer in der Bundesrepublik Deutschland. Anlass zur Einberufung der Synode und kirchenrechtlicher Status." In: Nationalsynoden (FN 24). Ed. J. SchmiedL, pp. 65-76; S. Voges: Die Gemeinsame Synode der Bistümer in der Bundesrepublik Deutschland. Themenfindung und Beteiligung der Öffentli...., pp. 225-235; P. LeIBINGER: „Gemeinsame Synode der Bistümer in der Bundesrepublik Deutschland 1971-1975." In: Synodale Prozesse (FN 26). Eds. W. ReEs, H. Müller, pp. 97-124; H. Hallermann: „Das Statut der Gemeinsamen Synode der Bistümer in der Bundesrepublik Deutschland." In: Unverbindliche Beratung (FN 44). Eds. W. ReEs, J. SCHMiedL, pp. 87-104.

${ }^{48}$ J. Јаковs: “Das Pastoralkonzil der niederländischen Kirchenprovinz (1966-1970). Eine neue Art der Autoritätsausübung." In: Nationalsynoden (FN 24). Eds. J. SchmiedL, pp. 57-64; J. Jаковs: Der Verlauf des Pastoralkonzils der niederländischen Kirchenprovinz, die behandelten Themen und das Resultat, ibid., pp. 217-224; J. B. M. Wissink: "Die Organisation des Niederländischen Pastoralkonzils." In: Unverbindliche Beratung (FN 44..., pp. 121-126.

${ }^{49}$ M. RiEs: "Auf der Suche nach Ausgleich. Die Schweizer Synode 72." In: Nationalsynoden (FN 24)..., pp. 101-115; R. WeIBeL: "Synode 72. Themenfindung und Beteiligung der Öffentlichkeit." Nationalsynoden (FN 24)..., pp. 236-257; M. BELoK: "Nationale Synoden im Ländervergleich: Die Synode 72 in der Schweiz (1972-1975)." In: Unverbindliche Beratung (FN 44),pp. 127-143.

50 See also S. Holzbrecher: "Die ostdeutsche Pastoralsynode in Dresden (19731975). In: Nationalsynoden (FN 24)," pp. 77-100; D. M. MeIER: "Das Statut der Pastoralsynode der Jurisdiktionbezirke in der DDR." In: Unverbindliche Beratung (FN 44)..., pp. 105-120. 
but also to preparations, topics, and corresponding legal perspective. Even if the participating bishops could be characterised very differently, there was a common agreement that the bishops themselves as well as the Austrian Bishops Conference as such thwarted, obstructed, and prevented the process in many ways. Many votes and advices had not been forwarded to Rome. Within the "establishment" of the Austrian Church there were tendencies to stay closed to the proposed reforms. The contemporary Austrian Church suffers from the ramifications of these events until today. Rarely decisions regarding structural changes and participation of the laity were made enforceable. Despite brave advices the then "hot potatoes" remained as such until today. All in all, the ASP is considered positive due to some its decisions and later implementations.

\section{Diocesan Synod and Plenary Council in CIC/1983 and other synodal processes in the Austrian Church}

CIC/1983, the code of canon law entered into force in 1983, provides for diocesan synods (cf. cc. 460—468 CIC/1983) and particular councils (cf. cc. 439-446 CIC/1983). ${ }^{51}$ As Joseph Listl mentions, some German diocese attempted to "enhance the goal of Diocesan Synod by non-legislatively Diocesan or Pastoral Panel" 52 since 1992, which is to be considered from various perspectives. Is it an expression of neither the will of individual diocesan bishops not being bound to the guidelines of CIC/1983 nor of a resignation regarding those bishops, who do not call for diocesan synods any longer due to the fact that its votes and results are not taken seriously?

The instruction of the Congregation for Bishops and the Congregation for the Evangelisation of People (19 March 1997) seeks for clarifica-

${ }^{51}$ Cf. H. Schmitz: “Die Konsultationsorgane des Diözesanbischofs.” In: HdbKathKR ${ }^{3}$, pp. 620-637, esp. pp. 622-626; see also W. ReEs: "Plenarkonzil und Bischofskonferenz." In: HdbKathKR ${ }^{3}$, pp. 543-576; G. BIER: "Die Kirchenprovinz.” In: HdbKAthKR3, pp. 577-584.

52 J. ListL: entry “Diözesansynode. I. Kirchenrechtlich.” In: LThK ${ }^{3}$, Vol. 3 (1995), p. 254. As the Kongregation FÜr DIE BISChÖFE: Direktorium für den Hirtendienst der Bischöfe vom 22. Februar 2004. No. 175, p. 236, to be found at: http://www.dbk-shop.de/media /files_public/orkqynbvby/DBK_2173.pdf (accessed 5.02.2020), emphasises it is "preferable to comply the substance of the canoncial law regarding Diocesan Synods as well as those instructions servatis servandis concerning panels or other ecclesiastical assemblies of synodal nature." Cf. H. Hallermann: Direktorium für den Hirtendienst der Bischöfe. Übersetzung und Kommentar (= KStKR, Volume 7). Paderborn-München-WienZürich 2006, p. 217. 
tion and tightening in guidelines concerning the implementation of diocesan synods. Therefore, admission criteria are clearly identified: besides firm belief, good manners and prudence canonic life situation is an imperative precondition for participation. ${ }^{53}$ If implementation of diocesan synod is given to the sole responsibility of diocesan bishops, the bishops are claimed in a particular way. After the ASP, there were four assemblies not celebrated as diocesan synods: Diözesantag of Erzdiözese Salzburg 1978, Diözesanforum of Erzdiözese Wien 1988-1992, Diözesanforum Innsbruck 1993, Diözesanforum Salzburg 1996 - all of them were Diocesan Penal. The Diocese of Innsbruck also decided to hold a Diocesan Penal (1993-1995) ${ }^{54}$ to discuss especially the following topics: "living Church in a parish," "regional pastoral- and personal planning," "marriage and family," "living with person with disabilities and the terminally ill," "women in the Church," "divorcees and divorced and remarried," 55 "homosexuals and faith," "youth," as well as "emulating bishops" ${ }^{56}$ and "Solidaritätsfonds der Diözese Innsbruck zur Förderung von Projekten für und mit schwervermittelbaren Arbeitslosen." Yet, Klaus Egger remarks in

53 Cf. Congregatio pro Episcopis, Congregatio pro Gentium Evangelizatione: "Instructio De Synodis dioecesanis agendis et Additamentum ad instructionem de Synodis dioecesanis agendis, II 3, $1^{\circ}$, referring to c. 512 2 CIC/1983.” In: AAS 89 (1997), pp. 706 721 and pp. $722-727$, here p. 711; to be found at: http://www.vatican.va/roman_curia/ congregations/cbishops/documents/rc_con_cbishops_doc_20041118_diocesan-syno ds-1997_lt.html (accessed 5.2.2020); in German: AfkKR 166 (1997), pp. 147-167, here p. 152; J. Hirnsperger: "Die Diözesansynode. Bemerkungen zu den einschlägigen Normen des CIC unter besonderer Berücksichtigung der Instruktion vom 19. März 1997.” In: Dem Staate, was des Staates - der Kirche, was der Kirche ist. Festschrift für Joseph Listl zum 70. Geburtstag. Ed. J. IsENSEe, W. REes, W. RüFNER (= Staatskirchenrechtliche Abhandlungen, Volume 33). Berlin 1999, pp. 855-873; J. Hirnsperger: "Die Diözesansynode. Bemerkungen zu den einschlägigen Normen des CIC unter besonderer Berücksichtigung der Instruktion vom 19. März 1997.” In: Synodale Prozesse (FN 26)..., pp. 55-75; H. HallermanN: "Ein Maulkorb aus Rom für mündige Christen? Die rechtliche Einordnung der römischen Instruktion über die Diözesansynoden." Diakonia 28 (1997), pp. 390-394.

${ }^{54}$ Cf. Bischöfliches Ordinariat - Seelsorgeamt Innsbruck (ed.): Diözesanforum Innsbruck 1993-1995. Innsbruck o. J (1995).

55 Cf. Bischöfliches Ordinariat der Diözese Innsbruck (ed.): Leitlinien der Diözese Innsbruck zur seelsorglichen Begleitung von Geschiedenen und Geschiedenen-Wiederverheirateten. Innsbruck 1997; following: SEelsorgeamt Der Diözese InNSBRUCK (ed.): Wenn geschiedene Menschen anlässlich ihrer standesamtlichen Trauung um ein Gebet bitten. Innsbruck 2008. In 2002 the Bishop of Innsbruck pointed to ecclesiastical ceremonies regarding this topic, expressly. Cf. Diözesanblatt. Amtliche Mitteilungen der Diözese Innsbruck, 77. Jg., Mai / Juni 2002, No. 3, TOP 32, p. 4.

56 According to this, the Diocesan Panel addresses a request "to the Apostolic Nuncio in Austria to consider the hopes, wishes and requests of particular churches by ordering bishops henceforth for the purpose of Can. 377 §3." 
1989 that Tyrolian Church "currently changed even more than within many decades before," ${ }^{57}$ since 1995 there has been no further diocesan synod or panel in Innsbruck. Similar considerations apply to the other Austrian dioceses. Entirely the Militärordinariat in Austria dared to hold a Diocesan Synod. ${ }^{58}$ Convocation of a diocesan synod by Military Bishop (30 September to 4 October 2013) exemplifies his will to count on joint responsibility of military chaplain and the laity..$^{59}$

The Diocese of Brixen-Bozen as well as the Diocese of Trier called for diocesan synods to take the right steps into future. Kardinal Schönborn (Archdiocese of Vienna) initiated a process called APG2010 to account for the challenges the Archdiocese faced around the turn of the millennium. The "Dialog für Österreich," which was audaciously commenced in 1998 and should be taken as a nationwide forum for discussion, "fell victim to machinations of the church politics." ${ }^{60}$ Nevertheless, there were further development processes in the Austrian dioceses.

57 Cf. Egger: Kirche in Tirol (FN 38)..., p. 19.

${ }^{58}$ Cf. H. Tripp: "Die Diözesansynode 2013 des Militärordinariates der Republik Österreich. Anmerkungen zur kanonistischen Praxis im pastoralen Prozess einer Teilkirche.” In: Synodale Prozesse (FN 26)..., pp. 335-362. Also the Dioceses of BozenBrixen and Trier convoked diocesan synods. See on that E. RungGaldier: "Syn-Odos: gemeinsam auf dem Weg. Die Synode der Diözese Bozen-Brixen 2013-2015." In: Synodale Prozesse (FN )...pp. 271-284; Auf Dein Wort Hin - Mit Freude und Hoffnung. Sulla Tua Parola - Con Gioia E Speranza. Sun Ti Parola - Con Legreza Y Speranza. 2013-2015 Synode Diözese Bozen-Brixen. Sinodo Diocesi Bolzano-Bressanone. Sinoda Diozeja Bulsan-Persenon. Bozen-Bolzano 2016; C. OHLY: “Die Diözesansynode im Bistum Trier (2012-2016). Anmerkungen aus kirchenrechtlicher Perspektive." In: Synodale Prozesse (FN 26).... pp. 207-235; G. Holkenbrink: "Das Wagnis einer Diözesansynode. Anmerkungen in der Zeit der Vorbereitung der Synode im Bistum Trier im Jahre 2013." In: Unverbindliche Beratung (FN 44)..., pp. 296-308.

${ }_{59}$ C. Werner: Militärbischof, Pastorale Leitlinien für das Militärordinariat der Republik Österreich. Schlussdokument der Diözesansynode 2013. Wien 2014; available online at: https://www.mildioz.at/dfs/query.php?radio_detail_d=2033 (accessed 5.02.2020); see also C. Werner: "Militärbischof, Ordnung der Diözesansynode vom September 2013 des Militärordinariats für die Republik Österreich vom 29. September 2012.” In: Militärordinariat der Republik Österreich, Amtsblatt Jg. 2012, 3. Oktober 2012, 1. Folge, Nr. II. 4, pp. 12-16;“Ordnung der Diözesansynode - Novelle vom September 2013 (30. August 2013)." In: Militärordinariat der Republik Österreich, Amtsblatt Jg. 2013, 2. September 2013, 1. Folge, Nr. I. 1, pp. 1-5.

${ }^{60}$ S. Laienrats-Präsident für neuen österreichweiten Dialogprozess. Laienrats-Präsident Theo Quendler vermisst eine „Gesprächsplattform auf gesamtösterreichischer Ebene“ und hofft nun auf einen neuen Anlauf (17.12.2016): https://www.erzdioezese-wien.at/site/ home/nachrichten/article/54299.html (accessed: 5.02.2020). 


\section{Conclusions}

Despite all discussions and criticism, diocesan synod and panel in Innsbruck initiated, due to urgent questions and appropriate votes, a lot of things shaping the diocese to this day. This also applies to other celebrated Austrian Diocesan Synods after the Second Vatican Council and to the APS. Currently, there is further erosion of consciousness and life in faith. Furthermore, the Austrian Roman Catholic Church faces such problems as the lack of priests and the large number of people leaving the Church. There are still many unaddressed topics in the past years still requiring solution. Therefore, the question remains if it is time for new synodal assemblies in Austria or if it is necessary to initiate a bigger process like the German "Synodaler Weg" (The Synodal Path). ${ }^{61}$ Due to the awakening instigated by Pope Francis regarding questions of transmission of faith, ecclesiastical structures, and togetherness as well as those issues which trouble the faithful today, ${ }^{62}$ the call for further processes becomes urgent.

If a certain awakening is mentioned today, ${ }^{63}$ the spiritual and religious awakening is meant as well as the one concerning ecclesiastical structures, forms of parish activities, time for actual pastoral care, new approaches to faithful. Those challenges require bold rethinking, new consulting processes and, in case of some issues, also a new regulation of law. There is much hope related to Pope Francis. In his speech on 17 October 2015 he emphasises synodality as the one way "God expects from his Church of the third decade." ${ }^{4}$ The current situation of the Austrian Church necessitates a new Austrian Synodal Process fifty years after the previous one. But a prerequisite for such a process is courage, openness, and willingness to search for ways for a sustainable Austrian Church. Therefore, one could learn by the experiences of ASP $^{65}$ and later Process of Dialogue. But it is

${ }^{61}$ On the German “Synodaler Weg," see: https://www.synodalerweg.de/ (accessed 5.02.2020).

${ }^{62}$ Cf. Franziskus: Apostolisches Schreiben „Evangelium Gaudium“ an die Bischöfe, an die Priester und Diakone, an die Personen Geweihten Lebens und an die Christgläubigen Laien über die Verkündigung des Evangeliums in der Welt von heute (2013): http://www .vatican.va/content/francesco/de/apost_exhortations/documents/papa-francesco_esortazi one-ap_20131124_evangelii-gaudium.html (accessed 5.2.2020).

${ }^{63}$ Franziskus: Ansprache bei der 50-Jahr-Feier der Errichtung der Bischofssynode vom 17. Oktober 2015: http://w2.vatican.va/content/francesco/de/speeches/2015/october/docu ments/papa-francesco_20151017_50-anniversario-sinodo.html (accessed 5.2.2020).

${ }^{64}$ Franziskus: Ansprache bei der 50-Jahr-Feier der Errichtung der Bischofssynode (FN 62).

${ }^{65}$ Cf. W. Rees: "Zeitzeugen erinnern sich an den Österreichischen Synodalen Vorgang." In: Die Erinnerung an die Synoden. Ereignis und Deutung - im Interview nach- 
also necessary to read the signs of the time already mentioned by Pope Francis in Evangelii Gaudium ${ }^{66}$ : the lack of priests, the dwindling interest in the Church, the people leaving the Church, the necessity to integrate the laity - especially women - into executive positions, the reorganisation of pastoral structures, the question of the Church's grasp for the concerns, fears, and aspirations of the people. Francis point to the signs of hope when he emphasises in Amoris Laetitia that divorced and remarried people can "receive sacramentary help in certain cases," so that the access to the Sacrament of the Eucharist is not sweepingly sealed to those anymore. ${ }^{67}$ The eyes of the universal Church were directed towards Vatican from 6 to 27 October 2019, where cardinals, bishops and experts conferred about "new ways for the Church and a holistic ecology" in Amazon region. Special emphasis was placed on priestly ordination of married men. ${ }^{68} \mathrm{~A}$ new order on the formation of priests ${ }^{69}$ and one for theological faculties (Veritatis Gaudium) ${ }^{70}$ has been adopted previously. In doing so,

gefragt (= Europas Synoden nach dem Zweiten Vatikanischen Konzil, Volume 4). Eds. J. SchmiedL, W. Rees. Freiburg-Basel-Wien 2017, pp. 304-506.

${ }^{66}$ FranZISKus: Evangelii Gaudium (FN 61), No. 102 and 103; Cf. also FranzISKus: Ansprache Weihnachtsempfang für die Römische Kurie am 22. Dezember 2016: https:// w2.vatican.va/content/francesco/de/speeches/2016/december/documents/papa-frances co_20161222_curia-romana.html (accessed 02.02.2016); see also: RADIO VATIKAN, Papst an Kurie: „Kein Fitnessraum für verborgenen Ehrgeiz“ (22.12.2016): http://www .archivioradiovaticana.va/storico/2016/12/22/papst_an_kurie_,kein_fitnessraum_für_ verborgenen_ehrgeiz“/de-1280868 (accessed 5.2.2020).

${ }^{67}$ Cf. Franziskus: Nachsynodales Apostolisches Schreiben „Amoris laetitia“ vom 19. März 2016 an die Bischöfe, an die Priester und Diakone, an die Personen Geweihten Lebens, an die christlichen Eheleute und an alle christgläubigen Laien über die Liebe in der Familie, Fn. 351, in: AAS; ferner unter: https://w2.vatican.va/content/francesco/de/apost exhortations/documents/papa-francesco_esortazione-ap_20160319_amoris-laetitia.html (accessed 5.2.2020).

${ }^{68}$ See katholisch.de: Amazonassynode, to be found at: https://www.katholisch.de /aktuelles/themenseiten/die-amazonas-synode (accessed 5.2.2020).

69 Cf. Kongregation für DeN KleRus: Das Geschenk der Berufung zum Priestertum. Ratio Fundamentalis Institutionis Sacerdotalis, 8. Dezember 2016: http://www.clerus .va/content/dam/clerus/Ratio\%20Fundamentalis/Das\%20Geschenk\%20der\%20Beru fung\%20zum\%20Priestertum.pdf (accessed 5.2.2020); see also W. ReEs: "Reformen in der römisch-katholischen Kirche. Kirchenrechtliche Neuerungen und Visionen von Papst Franziskus.” In: öarr 64 (2017), pp. 410-427 (= Festschrift für Herbert Kalb zum 60. Geburtstag); W. ReEs: "Strukturveränderungen in der Kirche. Am 13. März vor fünf Jahren wurde Kardinal Jorge Maria Bergoglio als Nachfolger auf den Stuhl Petri gewählt. Wie weit hat er seine radikalen Reformpläne umgesetzt? Was steht noch aus? Eine Zwischenbilanz.” In: SKZ. Schweizerische Kirchenzeitung 04/2018, 1. März 2018, 186. Jahrgang, pp. 92-93.

${ }^{70}$ W. ReEs: "Katholisch-Theologische Fakultäten und Priesterausbildung in Österreich. Historische Entwicklung, kirchen- und religionsrechtliche Vorgaben und Zukunftsperspektiven.” In: : Priesterausbildung. Ed. C. OHLy. Berlin 2020 (to be published). 
Pope Francis opened up to questions concerning the Austrian Church for more than 40 years. The Austrian Church is bound to face Pope Francis' request for reforms, whereby the texts and advices of the Second Vatican Council are still able to stimulate the process, even if the Council is a thing of the past for many people.

\section{Bibliography}

\section{Source documents}

Auf Dein Wort Hin - Mit Freude und Hoffnung. Sulla Tua Parola - Con Gioia E Speranza. Sun Ti Parola - Con Legreza Y Speranza. 2013-2015 Synode Diözese Bozen-Brixen. Sinodo Diocesi Bolzano-Bressanone. Sinoda Diozeja Bulsan-Persenon. Bozen-Bolzano 2016.

Bischöfliches ORDINARIAT DER DIÖZESe GuRK: Kirche für die Welt. Kärntner Diözesansynode 1971-1972. Klagenfurt o. J. 1975.

Bischöfliches OrdinaRiat Der Diözese InNSBRUCK (ed.): Leitlinien der Diözese Innsbruck zur seelsorglichen Begleitung von Geschiedenen und GeschiedenenWiederverheirateten. Innsbruck 1997.

Bischöfliches Ordinariat EISENSTADT (ed.): Zweite Synode der Diözese Eisenstadt. Eisenstadt 1990.

Bischöfliches Ordinariat InNSBRuck (ed.): Miteinander für alle. Das Pastoralprogramm der Diözese Innsbruck nach der Synode 1971-1972. Innsbruck o. J. 1974.

Bischöfliches Ordinariat - Seelsorgeamt InNSBRuck (ed.): Diözesanforum Innsbruck 1993-1995. Innsbruck o. J 1995.

Bischöfliches Ordinariat St. Pölten (ed.): Im Dienst an den Menschen. St. Pöltner Diözesansynode 1972. St. Pölten o. J. 1972.

Bischöfliches Seckauer Ordinariat in Graz (ed.): Der Laie in der Kirche. Seckauer

Diözesansynode 1960. Bericht und Statut, Graz o. J. 1961.

Diözesanblatt. Amtliche Mitteilungen der Diözese Innsbruck, 77. Jg. Mai/Juni 2002.

Diözese Eisenstadt (ed.): Diözese Eisenstadt auf dem Weg. Ihrem ersten Diözesanbischof DDr. Stefan László zum 80. Geburtstag. Redaktion Ägidius J. Zsifkovics. Innsbruck 1993.

Hirtenbrief von Bischof Elmar Fischer zum Advent 2008. Schwerpunkt seines Hirtenbriefs ist das 40-Jahr-Jubiläum der Diözese: http://www.kath-kirche -vorarlberg.at/artikel/2008/40-jahre-dioezese-feldkirch-2013-zwischen-ver gangenheit-und-zukunft.

Congregatio pro Episcopis, Congregatio pro Gentium EVANgelizatione: Instructio "De Synodis dioecesanis agendis" et Additamentum ad instructionem de Synodis dioecesanis agendis, II 3, $1^{\circ}$, referring to c. 512 § 2 CIC/1983. AAS 89 (1997), to be found at: http://www.vatican.va/roman_curia/congregations 
/cbishops/documents/rc_con_cbishops_doc_20041118_diocesan-synods -1997_lt.html (accessed 5.02.2020).

ERzBISChÖFliches OrdinARIAT Wien (ed.): Leben und Wirken der Kirche von Wien. Handbuch der Synode 1969-1971. Wien o. J. 1972.

FranZISKus: Ansprache bei der 50-Jahr-Feier der Errichtung der Bischofssynode vom 17. Oktober 2015: http://w2.vatican.va/content/francesco/de/speeches/2015/ october/documents/papa-francesco_20151017_50-anniversario-sinodo.html (accessed 5.02.2020).

FRANZISKUS: Ansprache Weihnachtsempfang für die Römische Kurie am 22. Dezember 2016: https://w2.vatican.va/content/francesco/de/speeches/2016/december/docu ments/papa-francesco_20161222_curia-romana.html (accessed 2.02.2016).

FranzISKus: Apostolisches Schreiben „Evangelium Gaudium“ an die Bischöfe, an die Priester und Diakone, an die Personen Geweihten Lebens und an die Christgläubigen Laien über die Verkündigung des Evangeliums in der Welt von heute (2013): http://www.vatican.va/content/francesco/de/apost_exhortations/docu ments/papa-francesco_esortazione-ap_20131124_evangelii-gaudium.html (accessed 5.02.2020).

FrANZISKUS: Nachsynodales Apostolisches Schreiben „Amoris laetitia“ vom 19. März 2016 an die Bischöfe, an die Priester und Diakone, an die Personen Geweihten Lebens, an die christlichen Eheleute und an alle christgläubigen Laien über die Liebe in der Familie, Fn. 351, in: AAS, to be found at: https://w2.vatican.va/ content/francesco/de/apost_exhortations/documents/papa-francesco_esortazione-ap_20160319_amoris-laetitia.html (accessed 5.02.2020).

GeNeralseKretariat DER WIENER DiÖZESANSYNODE IN DEN JAHREN 1967 BIS 1969 (ed.): Dokumentation der Wiener Diözesansynode 1967-69. Wien.

Kongregation Für DeN KleRus: Das Geschenk der Berufung zum Priestertum. Ratio Fundamentalis Institutionis Sacerdotalis, 8. Dezember 2016: http://www .clerus.va/content/dam/clerus/Ratio\%20Fundamentalis/Das\%20Ges chenk\%20der\%20Berufung\%20zum\%20Priestertum.pdf (accessed 5.02.2020).

Kongregation für DIE Bischöfe: Direktorium für den Hirtendienst der Bischöfe vom 22. Februar 2004. No. 175, p. 236, to be found at: http://www.dbk -shop.de/media/files_public/orkqynbvby/DBK_2173.pdf (accessed 5.2.2020).

Päpstliche Bulle zur Errichtung der Diözese Innsbruck vom 6. August 1964. In: Verordnungsblatt für die Diözese Innsbruck, 40. Jg., 4. Jänner 1965, Nr. 1, TOP 1, p. $1 \mathrm{f}$.

PAul VI: Apostolisches Schreiben anlässlich des fünften Jahrestages der Beendigung des Zweiten Vatikanischen Konzils vom 8. Dezember 1970. AAS 63 (1971), pp. 97-106 [online: http://www.kathpedia.com/index.php/Quinque_iam_ anni_(Wortlaut) (accessed 5.02.2020); http://w2.vatican.va/content/paul-vi /la/apost_exhortations/documents/hf_p-vi_exh_19701208_quinque-iam -anni.html (accessed 5.02.2020)].

Salzburger Diözesansynode 1968. Offizieller Text der Synodendekrete. Salzburg o. J. 1971.

SEelsorgeAmt Der Diözese InNSBruck (ed.): Wenn geschiedene Menschen anlässlich ihrer standesamtlichen Trauung um ein Gebet bitten. Innsbruck 2008. 
Sekretariat der linzer Diözesansynode (ed.): Kirche um der Menschen willen. Linzer Diözesansynode 1970-1972. 2 Volumes. Linz o. J. (1973).

SEelsorgeAmt Der Diözese InNSBRuck (ed.): Ich bin bei Euch. Mt 28,20. 25 Jahre Diözese Innsbruck. Innsbruck o. J. (1989) (accessed 5.02.2020).

\section{Secondary literature}

Althaus R.: entry “Gemeinsame Synode - Katholisch.” LKRR, Volume 2, pp. $189-191$.

Aymans W.: “Die Kirche - Das Recht im Mysterium Kirche." HdbKathKR 3 , pp. $32-41$.

BAusenhaRT G.: “Theologischer Kommentar zum Dekret über das Hirtenamt der Bischöfe in der Kirche." In: Herders Theologischer Kommentar zum Zweiten Vatikanischen Konzil, Volume. 3. Freiburg-Basel-Wien 2005, pp. 225313.

Belok M.: “Nationale Synoden im Ländervergleich: Die Synode 72 in der Schweiz (1972-1975)." In: Unverbindliche Beratung (FN 44). Eds. W. ReEs, J. SCHMIEDL, pp. 127-143.

Bier G.: “Die Kirchenprovinz.” HdbKAthKR3, pp. 577--584.

BURKARD D.: "Diözesansynoden und synodenähnliche Foren sowie Kirchenvolksbegehren der letzten Jahrzehnte in den deutschsprachigen Ländern.” RQ 101 (2006), pp. 113-140.

Cerny-Werner R.: "Diözesansynode als sichtbares Zeichen. Die Ausrufung der Diözesansynode 1968 in Salzburg als nachkonziliarer und regionaler Locus Theologicus." In: Synodale Prozesse in der katholischen Kirche. Ed. W. ReES, L. MüLLER. Innsbruck 2016, pp. 19-34.

Csoklich F.: “Die a-religiöse Religiosität des Österreichers. Verdunstende Kirchlichkeit unter barocken Kringeln.” HerKorr 28 (1974), pp. 405-412.

Egger K.: "Kirche in Tirol - Geschichte und Gegenwart." In: SeElsorgeamt der DiöZESE INNSBRUCK: Ich bin bei Euch, pp. 12-23.

ERdö P.: “Die Kirche als rechtlich verfaßtes Volk Gottes.” HdbKathKR ${ }^{2}$, pp. 12-20.

ERnesti J.: "Paul VI. Der vergessene Papst.” Freiburg-Basel-Wien 2012.

FEINE H.E.: Kirchliche Rechtsgeschichte, Volume I. Die Katholische Kirche. Köln 51972, pp. 215, 375 f., 713, 722; E. Cappellini, G. C. S. SARTORI: Il synodo diocesano. Storia, normativa, esperienza. Milano 1994.

Gelmi J.: “Die Errichtung der Diözesen Bozen-Brixen, Innsbruck-Feldkirch und Feldkirch. Eines der spannendsten Kapitel der neueren Tiroler Kirchengeschichte." In: Bischof Paulus Rusch. Wächter und Lotse in stürmischer Zeit. Gedenkschrift. Eds. H. AleXander, B. Kriegbaum. Innsbruck 2004, pp. 100-121.

Groner F.: “Trends in der katholischen Kirche im Bundesgebiet Deutschland nach dem Konzil." HerKorr 28 (1974), pp. 251-257.

HaERING S.: "Autorität und Synodalität im Gesetzbuch der lateinischen Kirche." In: Autorität und Synodalität. Eine interdisziplinäre und interkonfessionelle Umschau nach ökumenischen Chancen und ekklesiologischen Desideraten. Eds. C. Böttigheimer, J. Hofmann. Frankfurt am Main 2008, pp. 297-320. 
Hallermann H.: “Die Würzburger Synode - ein Maßstab für synodale Prozesse?" In: Recht - Bürge der Freiheit. Festschrift für Johannes Mühlsteiger SJ zum 80. Geburtstag. Ed. von Konrad Breitsching und W. Rees (= Kanonistische Studien und Texte, Volume 51). Berlin 2006, pp. 621-644.

Hallermann H.: entry “Communitas fidelium.” LKStKR Volume 1 (2000), pp. 357-359.

Hallermann H.: "Ein Maulkorb aus Rom für mündige Christen? Die rechtliche Einordnung der römischen Instruktion über die Diözesansynoden.” In: Diakonia 28 (1997), pp. 390-394.

Hallermann H.: entry “Gemeinde - Katholisch.” LKRR, Volume 2, pp. $162 \mathrm{f}$. Hallermann H.: entry “Gemeinsame Synode.” LKStKR 2 (2002), pp. 41-44.

Hallermann H.: "Das Statut der Gemeinsamen Synode der Bistümer in der Bundesrepublik Deutschland." In: Unverbindliche Beratung. Eds. W. ReES, J. SCHMiEDL, pp. 87-104.

Hallermann H.: Direktorium für den Hirtendienst der Bischöfe. Übersetzung und Kommentar (= KStKR, Volume 7). Paderborn-München-Wien-Zürich 2006.

Hartelt K.: Die Diözesan- und Regionalsynoden im deutschen Sprachraum nach dem Zweiten Vatikanum. Rechtshistorische und rechtstheologische Aspekte der Verwirklichung des Synodalprinzips in der Struktur der Kirche der Gegenwart (= Erfurter Theologische Studien, Volume 40). Leipzig 1979.

Неснт T.: Wir haben etwas zu sagen. Synodale Vorgänge in der Kirche Österreichs nach dem Zweiten Vatikanischen Konzil (= Diplomarbeit Katholisch-Theologische Fakultät der Universität Wien). Wien 1996.

Hirnsperger J.: “Die Diözesansynode. Bemerkungen zu den einschlägigen Normen des CIC unter besonderer Berücksichtigung der Instruktion vom 19. März 1997." In: Dem Staate, was des Staates - der Kirche, was der Kirche ist. Festschrift für Joseph Listl zum 70. Geburtstag. Ed. von Josef ISENSEE, W. REES und Wolfgang RÜFNER (= Staatskirchenrechtliche Abhandlungen, Volume 33). Berlin 1999, pp. 855-873.

Hirnsperger J.: Die Diözesansynode. Bemerkungen zu den einschlägigen Normen des CIC unter besonderer Berücksichtigung der Instruktion vom 19. März 1997. In: Synodale Prozesse in der katholischen Kirche. Innsbruck 2016, pp. 55-75.

Hofmann J. (ed.): Autorität und Synodalität. Eine interdisziplinäre und interkonfessionelle Umschau nach ökumenischen Chancen und ekklesiologischen Desideraten. Frankfurt am Main 2008, pp. 237-251.

Ноцвӧск C.: “Die Salzburger Diözesansynode 1968.” In: Ius et salus animarum. Festschrift für Bernhard Panzram (= Sammlung Rombach, NF. Volume 15). Ed. von U. MOSIEK und H. ZAPP. Freiburg 1972, pp. 379-391.

Holkenbrink G.: “Das Wagnis einer Diözesansynode. Anmerkungen in der Zeit der Vorbereitung der Synode im Bistum Trier im Jahre 2013.” In: Unverbindliche Beratung. Eds. W. ReEs, J. SchmiedL, pp. 296-308.

Holzbrecher S.: Die ostdeutsche Pastoralsynode in Dresden (1973-1975), in: SCHMIEDL: Nationalsynoden (FN 24), pp. 77-100.

Jаковs J.: Das Pastoralkonzil der niederländischen Kirchenprovinz (1966-1970). 
Eine neue Art der Autoritätsausübung, in: J. SchmiEdL: Nationalsynoden, pp. 57-64.

JаковS J.: Der Verlauf des Pastoralkonzils der niederländischen Kirchenprovinz, die behandelten Themen und das Resultat, in: JaKовs: Das Pastoralkonzil, pp. $217-224$.

LAPPEN F.: Vom Recht zu reden und vom Recht gehört zu werden. Synoden und Foren als Mittel der Teilhabe der Gläubigen an den Leitungsfunktionen der Kirche in Deutschland (= Münsterischer Kommentar zum Codex Iuris Canonici, Beiheft 46), Essen 2007, pp. 4-9.

LÁszló S.: Die Synoden der Diözese Eisenstadt. Ein Beitrag zur Rechts- und Kirchengeschichte, in: Kaluza / Klecatsky / KöcK / PaArhammer: Pax et Iustitia, pp. 591-599.

Lehrbuch des Kirchenrechts auf Grund des Codex Iuris Canonici. Begründet von Eduard Eichmann, fortgeführt von Klaus Mörsdorf, Volume I: Einleitung, Allgemeiner Teil und Personenrecht (= Wissenschaftliche Handbibliothek. Eine Sammlung theologischer Lehrbücher), München — Paderborn — Wien ${ }^{11} 1964$.

LeIBINGer P.: Gemeinsame Synode der Bistümer in der Bundesrepublik Deutschland 1971-1975, in: REES / MÜLLER: Synodale Prozesse, pp. 97-124.

Listl J.: Art. Diözesansynode. I. Kirchenrechtlich, in: LThK ${ }^{3}$, Volume 3 (1995), p. 254.

MAuer O.: Situation 1965. Die österreichische Kirche im Zeitalter des ökumenischen Konzils, in: Klostermann, F., Kriegl, H., Mauer, O., Weinzierl, E. (eds.): Kirche in Österreich 1918-1965, Volume 1, Wien — München 1966, pp. 387-403.

Meckel T.: Art. Allgemeines bzw. Gemeinsames Priestertum - Katholisch, in: LKRR, Volume. 1, pp. 83-87.

Meckel T.: Art. Communio - Katholisch, in: LKRR, Volume 1, pp. 518-520.

MeIer D. M.: Das Statut der Pastoralsynode der Jurisdiktionbezirke in der DDR, in: Rees / SCHMIEDL: Unverbindliche Beratung, pp. 105-120.

Monceau H.: Les synodes diocésains, Paris 1994.

Müller H.: Kirchliche communio und Struktur der Mitverantwortung in der Kirche. Vom Zweiten Vatikanischen Konzil zum Codex Iuris Canonici, in: AfkKR 159 (1990), pp. 117-131.

Nikolakopoulos K.: Neutestamentliche Wurzeln der Synodalität, in: BötTIGHEIMER, C. G., Ohly C., Die Diözesansynode im Bistum Trier (2012-2016). Anmerkungen aus kirchenrechtlicher Perspektive, in: ReEs / MülLER: Synodale Prozesse, pp. $207-235$.

PAARHAMmer H.: Die Diözesansynode in ihrer gegenwärtigen Rechtsgestalt. Anmerkungen zum geltenden Recht und zu partikulären Neuentwicklungen des kirchlichen Synodalwesens auf Diözesanebene, in: Lüdicke, K., PAARHAMMER, H., Binder, D. A., (Ed.): Neue Positionen des Kirchenrechts, Graz 1994, pp. $81-117$.

PuzA R.: Le principe synodale et les deux types des synodes entre le Code de 1917 et le Code de 1983, in: Melloni, A., Scatena, S.: (Eds.), Synod and Synodality. 
Theology, History, Canon Law and Ecumenism in new contact. International Colloquium Bruges 2003 (= Christianity and History Vol. 1), Münster 2005, pp. 647-662.

RAHner K.: Zur Theologie einer „Pastoralsynode“, in: HüBner, S. (Ed.): Theologisches Jahrbuch 1973, Leipzig 1983, pp. 507-518.

ReEs W.: Aufbruch durch die Diözesansynode 1971/72 in der neu errichteten Diözesen Innsbruck, in: Paarhammer, H., Rinnerthaler A. (Ed.): Kirchlicher Wiederaufbau in Österreich (= Wissenschaft und Religion, Volume 26), Frankfurt am Main u.a. 2016, pp. 723-758.

REes W.: Der Österreichische Synodale Vorgang (1973/74). Vorgeschichte und kirchenrechtlicher Status, in: J. Schmiedel (Ed.): Nationalsynoden nach dem Zweiten Vatikanischen Konzil. Rechtliche Grundlagen und öffentliche Meinung (= Theologische Berichte XXXV), Freiburg — Schweiz 2013, pp. 116-198.

ReEs W.: Die Diözesansynode Innsbruck 1971/72, in: ReEs / Müller, Synodale Prozesse, pp. 237-269.

ReEs W.: Geistlicher Aufbruch - gestern und heute. Die Diözesansynode Innsbruck 1971/72 im Rahmen synodaler Prozesse. Anmerkungen aus kirchenrechtlicher Perspektive, in: Diözese InNSBRuck (Ed.), Notae. Historische Notizen zur Diözese Innsbruck, Innsbruck 2014, pp. 112-146.

REes W.: Katholisch-Theologische Fakultäten und Priesterausbildung in Österreich. Historische Entwicklung, kirchen- und religionsrechtliche Vorgaben und Zukunftsperspektiven, in: OHLY, C.: Priesterausbildung, Berlin 2020 (just to be published).

Rees W.: Plenarkonzil und Bischofskonferenz, in: HdbKathKR ${ }^{3}$, pp. 543-576.

REES W.: Reformen in der römisch-katholischen Kirche. Kirchenrechtliche Neuerungen und Visionen von Papst Franziskus. öarr 64 (2017), pp. 410-427.

ReEs W.: Strukturveränderungen in der Kirche. Am 13. März vor fünf Jahren wurde Kardinal Jorge Maria Bergoglio als Nachfolger auf den Stuhl Petri gewählt. Wie weit hat er seine radikalen Reformpläne umgesetzt? Was steht noch aus? Eine Zwischenbilanz, in: SKZ. Schweizerische Kirchenzeitung 04/2018, 1. März 2018, 186. Jahrgang, pp. 92-93.

ReEs W.: Synoden und Konzile. Geschichtliche Entwicklung und Rechtbestimmungen in den kirchlichen Gesetzbüchern von 1917 und 1983, in: W. ReES, Schmiedi, J. (Ed.): Unverbindliche Beratung oder kollegiale Steuerung? Kirchenrechtliche Überlegungen zu synodalen Vorgängen (= Europas Synoden nach dem Zweiten Vatikanischen Konzil), Freiburg-Basel-Wien 2014, pp. $10-67$.

REES W.: Zeitzeugen erinnern sich an den Österreichischen Synodalen Vorgang, in: Schmiedl, J., Rees, W. (Ed.): Die Erinnerung an die Synoden. Ereignis und Deutung - im Interview nachgefragt (= Europas Synoden nach dem Zweiten Vatikanischen Konzil, Volume 4), Freiburg - Basel - Wien 2017, pp. 304-506.

Riedel-Spangenberger I.: entry Communio, in: LKStKR, Volume 1 (2000), pp. 355-357;

Riedel-SPANGENBERGER I.: entry Gemeinsames Priestertum. II. Kath., in: LKStKR, Volume 2 (2002), pp. 44-45; 
RIES M.: Auf der Suche nach Ausgleich. Die Schweizer Synode 72, in: ScHMIEdL: Nationalsynoden, pp. 101-115.

Rozkrut T.: La natura teologico-giuridica del sinodo diocesano (= Ponticium Athenaeum Sanctae Crucis Facultas Iuris Canonici), Roma 1996.

Runggaldier E.: Syn-Odos: gemeinsam auf dem Weg. Die Synode der Diözese BozenBrixen 2013-2015, in: Rees / Müller: Synodale Prozesse, pp. 271-284.

Schmitz H.: Die Beratungsorgane des Diözesanbischofs, in: GrNKirchR, pp. 277287.

Schmitz H.: Die Konsultationsorgane des Diözesanbischofs, in: HdbKathKR ${ }^{3}$, pp. $620-637$.

SchöDl I.: Vom Aufbruch in die Krise. Die Kirche in Österreich ab 1945 (= Editio Ecclesia semper reformanda 6), Innsbruck - Wien 2011.

Schulz W.: Diözesan- und Regionalsynoden in den deutschsprachigen Ländern. Erfahrungen und Perspektiven, in: La Synodalité. La participation au gouvernement dans l'Église. Actes du VII $\mathrm{e}^{\mathrm{e}}$ congrès international de Droit canonique, Paris, Unesco, 21-28 septembre 1990, Paris 1992, pp. 629-649.

Tripp H.: Die Diözesansynode 2013 des Militärordinariates der Republik Österreich. Anmerkungen zur kanonistischen Praxis im pastoralen Prozess einer Teilkirche, in: ReEs / Müller: Synodale Prozesse, pp. 335-362.

Übersicht über den Stand der synodalen Arbeit, in: Synode Wien. Information Bericht Dokumente 1/67, p. 1.

Voges S.: Die Gemeinsame Synode der Bistümer in der Bundesrepublik Deutschland. Anlass zur Einberufung der Synode und kirchenrechtlicher Status, in: SCHMIEDL: Nationalsynoden pp. 65-76.

Voges S.: Die Gemeinsame Synode der Bistümer in der Bundesrepublik Deutschland. Themenfindung und Beteiligung der Öffentlichkeit, in: SCHMIEDL: Nationalsynoden, pp. 225-235.

Wagner A.: Kirche in Österreich nach der Synode, in: Lebendige Seelsorge 27 (1976), pp. 105-110.

WeIBEL R.: Synode 72. Themenfindung und Beteiligung der Öffentlichkeit, in: RIES: Auf der Suche, pp. 236-257.

Werner C.: Militärbischof, Ordnung der Diözesansynode vom September 2013 des Militärordinariats für die Republik Österreich vom 29. September 2012, in: Militärordinariat der Republik Österreich, Amtsblatt Jg. 2012, 3. Oktober 2012, 1. Folge, Nr. II. 4, pp. 12-16.

Werner C.: Militärbischof, Pastorale Leitlinien für das Militärordinariat der Republik Österreich. Schlussdokument der Diözesansynode 2013, Wien 2014, to be found at: https://www.mildioz.at/dfs/query.php?radio_detail_d=2033 (accessed 5.2.2020).

Werner C.: Ordnung der Diözesansynode - Novelle vom September 2013 (30. August 2013), in: Militärordinariat der Republik Österreich, Amtsblatt Jg. 2013, 2. September 2013, 1. Folge, Nr. I. 1, pp. 1-5.

Widrich H. (ed.): Erneuerung der Erzdiözese Salzburg durch lebendige Christengemeinden. Bericht und Dokumentation über die Salzburger Diözesansynode 1968 (= Dokumentation unserer Zeit), Wien 1969. 
Witsch N.: Art. Diözesansynode - Katholisch, in: LKKR, Volume 1, pp. 644646.

Witsch N.: Art. Synodalität, in: LKStKR, Volume 3 (2004), pp. 642-644.

Witsch N.: Synodalität auf Ebene der Diözese. Die Bestimmungen des universalkirchlichen Rechts der Lateinischen Kirche (= KStKR 1). PaderbornMünchen-Wien-Zürich 2004.

Witsch N.: entry Volk Gottes, in: LKStKR, Volume 3 (2004), pp. 840-842.

Wissink J. B. M.: Die Organisation des Niederländischen Pastoralkonzils, in: ReEs / SCHMIEDL: Unverbindliche Beratung, pp. 121-126.

Zulehner P. M.: Religiös-kirchliche Daten in Österreich, in: HerKorr 28 (1974), pp. 580-584,

Zulehner P. M.: Säkularisierung von Gesellschaft, Person und Religion. Religion und Kirche in Österreich, Wien 1973.

Zulehner P. M.: Verfällt die Kirchlichkeit in Österreich?, Graz 1971.

Zulehner P. M.: Die kirchlichen Institutionen, in: Fischer, H. (Ed.): Das politische System Österreichs, Wien 1974, pp. 625-641.

Österreich-Synode im Aufschwung. HerrKorr 28 (1974), pp. 37-40.

Synodenvielfalt in Österreich. HerKorr 25 (1971), pp. 34-37.

Das Ende der Österreich-Synode. HerKorr 28 (1974), pp. 368-372.

\section{Online Sources}

Der Synodale Weg, to be found at: https://www.synodalerweg.de/ (accessed 5.2.2020).

Laienrats-Präsident für neuen österreichweiten Dialogprozess. Laienrats-Präsident Theo Quendler vermisst eine „Gesprächsplattform auf gesamtösterreichischer Ebene“ und hofft nun auf einen neuen Anlauf (17.12.2016), to be found at: https://www.erzdioezese-wien.at/site/home/nachrichten/article/54299.html (Zugriff 5.2.2020).

Amazonassynode, (www.katholisch.de), to be found at: https://www.katholisch .de/aktuelles/themenseiten/die-amazonas-synode (accessed 5.2.2020).

Papst an Kurie: „Kein Fitnessraum für verborgenen Ehrgeiz“ (Radio Vatican, 22.12.2016), to be found at: http://www.archivioradiovaticana.va/storico /2016/12/22/papst_an_kurie_,kein_fitnessraum_für_verborgenen_ehrgeiz“ /de-1280868 (accessed 5.2.2020). 
WILHELM REES

\title{
Synodes et synodalité dans l'Église autrichienne après le Concile Vatican II
}

\author{
Résumé
}

Les synodes ont une longue tradition dans l'histoire ecclésiastique, bien que, dans l'Église catholique romaine, leur importance ait varié selon les époques. En Europe, les synodes ont suscité de l'intérêt après le Concile Vatican II, bien qu'ils soient apparus sous une forme nouvelle ou plutôt modifiée. Cela vaut également pour les synodes diocésains et le processus synodal autrichien (1973/1974) qui a eu lieu un peu plus tard et a été organisé par les leaders d'opinion du Concile Vatican II.

Mots-clés: synodalité, droit canonique, Concile Vatican II, République d'Autriche, Codex Iuris Canonici

WILHELM REES

\section{Sinodi e sinodalità nella Chiesa austriaca dopo il Concilio Vaticano II}

\author{
Sommario
}

I sinodi hanno una lunga tradizione nella storia ecclesiastica, anche se la loro importanza variava nella Chiesa cattolica romana a seconda delle epoche. In Europa, i sinodi acquisirono importanza dopo il Concilio Vaticano II, sebbene in quel momento apparissero in una forma nuova o piuttosto modificata. Ciò vale anche per i sinodi diocesani e per il processo sinodale austriaco (1973/1974) che ebbe luogo un po' più tardi ed fu organizzato dai promotori del pensiero del Concilio Vaticano II.

Parole chiave: sinodalità, diritto canonico, Concilio Vaticano II, Repubblica d'Austria, Codex Iuris Canonici 